\title{
STUDI KASUS GANGGUAN POLA NAPAS TIDAK EFEKTIF PADA PASIEN EFUSI PLEURA
}

\author{
Yunita Devi Anggarsari,Yuyun Setyorini,Akhmad Rifai \\ Kementerian Kesehatan Politeknik Kesehatan Surakarta Jurusan Keperawatan \\ Diterima : 12 Oktober 2018, Disetujui : 30 Oktober 2018
}

\begin{abstract}
Background: Pleural effusion is a fluid above the normal in the pleural space. Widespread pleural effusions will cause shortness of breath that affects the fulfillment of oxygen demand, so that nursing interventions can be arranged one of them is to set the semifowler position and collaborate in the giving of $\mathrm{O}_{2}$. The purpose of this study was to obtain a picture and experience in providing nursing care significantly for patients with pleural effusion with respiratory disorders. Method: This study uses data analysis method that is comparing the results obtained from two patients with pleural effusions who experienced ineffective breathing disorder and then compared with case study journal or other sources. Result: Based on the results of interviews and observations concluded that with the same diagnosis and performed the same implementation there are differences in outcomes in the intervention group with the control group. Conclusion: Forward in this study is the need to pay attention to accuracy in conducting assessments to maximize data in determining the priority problems that occur in patients and interventions based ONEC (Observation, Nursing Treatment, Education, Collaboration).
\end{abstract}

Keywords: Pleural Effusion; Breath Pattern Not Effective

\section{PENDAHULUAN}

Efusi pleura adalah penumpukan cairan pada rongga pleura. Cairan pleura normalnya merembes secara terus menerus ke dalam rongga dada dari kapiler - kapiler yang membatasi pleura parietalis dan diserap ulang oleh kapiler dan sistem limfatik pleura viseralis. Kondisi apapun yang mengganggu sekresi atau drainase dari cairan ini akan menyebabkan efusi pleura (Black \& Hawks, 2014).

Menurut Smelter 2001 dalam Wahyuningtyas (2012) efusi pleura adalah penimbunan cairan dalam rongga pleura akibat transudasi atau eksudasi yang berlebihan dari permukaan pleura. Dalam keadaan normal, rongga pleura hanya mengandung sedikit cairan sebanyak $10-$
$20 \mathrm{ml}$ yang membentuk lapisan tipis pada pleura perietalis dan viserali yang berfungsi sebagai pelicin antar kedua pleura pada waktu pernafasan. Penyakit penyakit yang dapat menimbulkan efusi pleura adalah tuberculosis, infeksi paru non tuberculosis, keganasan, sirosis hati, trauma tembus atau tumpul pada daerah dada, infark paru, serta gagal jantung kongestif.

Di Amerika Serikat, setiap tahunnya terjadi 1,5 juta kasus efusi pleura. Sementara pada populasi umum secara internasional diperkirakan setiap 1 juta orang, 3000 orang terdiagnosis efusi pleura. Di negara-negara berat, efusi pleura terutama disebabkan oleh gagal jantung kongestif, sirosis hati, keganasan, dan pneumonia bakteri. Di negara sedang 
berkembang seperti Indonesia, lazim diakibatkan oleh infeksi tuberkulosis. Di Indonesia, kasus efusi pleura mencapai $2,7 \%$ dari penyakit infeksi saluran napas lainnya. Tingginya angka kejadian efusi pleura ini disebabkan keterlambatan penderita untuk memeriksakan kesehatan sejak dini. Faktor resiko terjadinya efusi pleura diakibatkan karena lingkungan yang tidak bersih, sanitasi yang kurang, lingkungan yang padat penduduk, kondisi sosial ekonomi yang menurun, serta sarana dan prasarana kesehatan yang kurang dan kurangnya masyarakat tentang pegetahuan kesehatan (Puspita, Soleha, \& Berta, 2015).

Di RSDM Surakarta dari 107 pasien efusi pleura ditemukan bahwa laki-laki sebanyak 51 orang $(47,66 \%)$ dan perempuan 56 orang $(52,34 \%)$. Keluhan utama yang membawa pasien berobat ke RSDM terbanyak dengan sesak napas 62 pasien $(57,94 \%)$, disusul batuk ada 35 pasien $(32,71 \%)$, nyeri dada 7 pasien $(6,54 \%)$, batuk darah ada 2 pasien $(1,84 \%)$, dan nyeri perut ada 1 pasien $(0,93 \%)$ (Surjanto, Sutanto, Aphridasari, \& Leonardo, 2015).

Gejala yang sering timbul pada efusi pleura adalah sesak napas. Nyeri bisa timbul akibat efusi yang banyak berupa nyeri dada pleuritik atau nyeri tumpul bergantung pada jumlah akumulasi cairan. Efusi pleura yang luas akan menyababkan sesak napas yang berdampak pada pemenuhan kebutuhan oksigen, sehingga kebutuhan oksigen dalam tubuh kurang terpenuhi. Hal tersebut dapat menyebabkan metabolisme sel dalam tubuh tidak seimbang. Oleh karena itu, diperlukan pemberian terapi oksigen (Morton, Fontaine, Hudak, Gallo, 2013).

Berdasarkan pengalaman di rumah sakit, pemberian oksigen pada pasien efusi pleura sangat diperhatikan karena kondisi pasien yang sesak napas dan perubahan saturasi oksigen. Selain itu dengan pemberian oksigen yang tepat akan membantu memaksimalkan pernapasan dan mengurangi kerja napas.

\section{METODE PENELITIAN}

Peneliti menggunakan jenis rancangan deskriptif. Menurut Nursalam (2016) desain studi kasus deskriptif bertujuan untuk memaparkan peristiwaperistiwa penting yang terjadi pada masa kini. Deskripsi peristiwa dilakukan secara sistematis dan lebih menekankan pada data faktual daripada penyimpulan. Fenomena disajikan secara apa adanya tanpa manipulasi dan tidak dianalisis bagaimana dan mengapa fenomena tersebut bisa terjadi, oleh karena itu rancangan deskriptif ini tidak memerlukan adanya suatu hipotesis.

Jenis rancangan deskriptif yang digunakan adalah rancangan penelitian studi kasus. Studi kasus merupakan rancangan penelitian yang mencakup pengkajian satu unit penelitian secara intensif misal klien, keluarga, kelompok, komunitas atau institusi. Rancangan dari suatu studi kasus bergantung pada keadaan kasus namun tetap mempertimbangkan faktor penelitian waktu. Keuntungan yang paling besar dari rancangan ini adalah pengkajian secara terperinci meskipun jumlah responden sedikit, sehingga akan didapatkan gambaran unit subjek secara jelas (Nursalam, 2016).

Studi kasus ini bertujuan untuk memberikan gambaran tentang asuhan keperawatan pada pasien efusi pleura dengan gangguan pola napas tidak efektif yang meliputi pengkajian, diagnosa, intervensi, implementasi sampai dengan 
evaluasi keperawatan melalui wawancara dan observasi sehingga desain studi kasus ini menggunakan jenis dan rancangan deskriptif dengan pendekatan studi kasus.

1. Subyek Studi Kasus

Subyek studi kasus dalam asuhan keperawatan ini adalah Tn. D dan Tn. J dengan efusi pleura yang mengalami masalah keperawatan pola napas tidak efektif.

2. Pengumpulan Data

a. Metode Pengumpulan Data

Pengumpulan data adalah suatu proses pendekatan kepada subjek dan proses pengumpulan karakteristik subjek yang diperlukan. Langkah-langkah dalam pengumpulan data bergantung pada rancangan studi kasus dan teknik instrumen yang digunakan. Selama proses pengumpulan data peneliti memfokuskan pada penyediaan subjek, melatih tenaga pengumpul data (jika diperlukan), memperhatikan prinsip-prinsip validitas dan reabilitas, serta menyelesaikan masalah-masalah yang terjadi agar data dapat terkumpul sesuai rencana (Nursalam, 2016).

Teknik pengumpulan data menggunakan data primer dan sekunder. Pengumpulan data yang digunakan dalam studi kasus ini adalah :

1) Data primer merupakan data yang didapatkan secara langsung

a) Observasi

Observasi merupakan cara pengumpulan data dengan mengadakan pengamatan secara langsung kepada responden penelitian untuk mencari perubahan atau hal-hal yang akan diteliti. Bentuk observsi ada tiga yaitu observasi partisipasi, observasi tidak terstuktur dan observasi kelompok. Dalam metode observasi ini, instrumen yang digunakan anatara lain lembar observasi, panduan pengamatan, atau lembar checklis (Hidayat, 2014). Observasi dalam studi kasus ini menggunakan metode observasi partisipatif dilakukan untuk pengumpulan data dan mengetahui perkembangan pasien.

b) Wawancara

Wawancara merupakan metode pengumpulan data dengan cara mewawancarai langsung responden yang diteliti, sehingga metode ini memberikan hasil secara langsung. Jenis wawancara yang digunakan diantaranya wawancara mendalam dan wawancara terarah (Hidayat, 2014). Wawancara dapat dilakukan melalui dua cara yaitu auto anamnesa dan allo anamnesa

c) Pemeriksaan fisik

Menurut Black \& Hawks (2014) pemeriksaan fisik dapat dilakukan melalui empat cara :

Inspeksi (I). Amati irama, frekuensi, dan kedalaman pernapasan. Frekuensi pernapasan normal orang dewasa mencapai 14-20 x/menit. Amati tanda gagal napas seperti pernapasan cuping hidung.

Perkusi (P) : Perkusi pada jaringan paru yang sehat menghasilkan suatu resonan (suara bernada rendah, berongga). Nada dan kualitas suara perkusi lain dapat dirangkum sebagai berikut: (1) timpani (nada tinggi, bergaung, seperti drum), (2) datar (nada tinggi, lembut), (3) pekak (nada sedang, seperti suara "gedebugsuara tubuh yang jatuh). Palpasi (P). Palpasi trakea, kaji apakah posisisnya berada di garis tengah dan dapat bergerak sedikit. Palpasi dinding dada untuk mengkaji pengembangan dada simetris atau tidak selama inspirasi dan ekspirasi. Palpasi untuk menilai fremitus taktil dengan cara palpasi dinding dada posterior 
ketika klien berkata "sembilan puluh sembilan".

Auskultasi (A). Auskultasi paru memberikan data pengkajian kritis untuk menentukan kesehatan klien. Auskultasi semua area paru di atas dada telanjang untuk mendapatkan temuan akurat. Pada setiap lokasi auskultasi, dengarkan suatu siklus respirasi yang meliputi inspirasi dan ekspirasi saat klien bernapas melalui mulut. Auskultasi tipe atau karakter suara pernapasan, dan adanya suara tambahan.

2) Data sekunder adalah data yang didapatkan secara tidak langsung

a) Studi kepustakaan

Studi kepustakaan adalah kegiatan penelitian yang dilakukan oleh peneliti dalam rangka mencari landasan teoritis dari permasalahan (Hidayat, 2014). Pada kasus ini menggunakan studi kepustakaan yang bersumber dari buku kesehatan, buku ilmu keperawatan, jurnal laporan laporan hasil penelitian dari sumber terbaru.

b) Dokumentasi

Dokumentasi merupakan metode pengumpulan data dengan cara mengambil data yang berasal dari dokumen asli (Hidayat, 2014). Dokumen asli tersebut dapat berupa pemeriksaan atau catatan medis klien, rekam medis, hasil laboratorium serta terapi.

3. Metode Analisis Data (Domain Analisis)

Dalam studi kasus ini peneliti membandingkan kriteria hasil yang dicapai dari 2 pasien efusi pleura yang mengalami gangguan pola napas tidak efektif dan kemudian dibandingkan dengan jurnal studi kasus ataupun sumbersumber lain (jurnal, buku, dll).

\section{HASIL PENELITIAN}

1. Pengkajian

a. Tn. D

Pengkajian dilakukan pada tanggal 5 Maret 2018 pukul 14.00 WIBdi ruang HCU Anggrek 1 RS Dr. Moewardi Surakarta. Data didapat dari hasil observasi, wawancara langsung, pemeriksaan fisik, dan dari status pasien. Hasil pengkajian diperoleh data: nama pasien adalah Tn. D, jenis kelamin lakilaki, alamat rumah Sragen, usia 40 tahun, pendidikan SMA, pekerjaan karyawan swasta, status perkawinan menikah, no RM 01410xxx, Dx. medis efusi pleura. Identitas penanggung jawab: nama $\mathrm{Ny}$. F, jenis kelamin perempuan, alamat rumah Sragen, pekerjaan karyawan swasta, hubungan dengan pasien adalah istri.

Keluhan utama yang dirasakan pasien yaitu sesak napas, batuk, dan nyeri dada. Riwayat penyakit sekarang yaitu pasien masuk rumah sakit pada tanggal 25 Februari 2018 pukul 17.00 WIB melalui IGD dengan keluhan batuk, sesak napas, dan nyeri dada. Batuk berdahak sejak 7 bulan yang lalu yang dirasa semakin memberat sejak 2 bulan sebelum masuk RSDM. Sebelum dirawat di RSDM pasien sempat dirawat di RS Panti Waluyo, di RS Panti Waluyo pasien mendapatkan pengobatan rawat jalan dan akhirnya mendapat rujukan ke RSDM. Riwayat penyakit dahulu yaitu pasien mengatakan belum pernah menderita penyakit paru sebelumnya. Riwayat penyakit keluarga yaitu pasien mengatakan di dalam keluarga pasien tidak ada yang menderita penyakit paru ataupun penyakit menular lainya. Riwayat pekerjaan dan gaya hidup yaitu pasien mengatakan bekerja di salah satu pabrik yang ada di daerah sragen dan pasien pengguna narkoba. 
Hasil pengkajian primer yaitu airway: bebas sumbatan jalan napas, suara napas kanan vesikuler, kiri vesikuler yang menurun di ICS II, III, ICS V, VI. Breathing: pasien mengalami sesak napas, berrnapas menggunakan otot bantu pernapasan, RR 28 x/menit, irama napas teratur, tidak ada tanda distres pernapasan. Circulation: akral hangat, tidak pucat, tidak ada sianosis, CRT: $<2$ detik, nadi 95 $\mathrm{x} / \mathrm{menit}$, irama nadi teratur kuat, TD $101 / 70 \mathrm{mmHg}$, kulit lembab, turgor kulit normal. Disability: tingkat kesadaran composmentis, GCS $\mathrm{E}_{4} \mathrm{~V}_{5} \mathrm{M}_{6}$, Pupil isokor, reflek cahaya $+/+$, besar pupil 3/3. Eksposure: tidak ada trauma dan jejas pada tubuh, terpasang WSD sebelah kiri.

Hasil pengkajian sekunder yaitu Sign and Symptoms: pasien mengalami batuk berdahak, nyeri dada, dan sesak napas. pasien megatakan sesak napas ketika pasien tidur dengan posisi telentang, dan saat pasien beraktivitas berat. Allergies: pasien tidak ada alergi obat, debu, makanan. Medication: pasien tidak sedang menjalani pengobatan lain. Past illnes: pasien tidak pernah menderita penyakit lain sebelumnya. Last oral intake: pasien mengkonsumsi obat dari RS. Event: Pasien masuk rumah sakit pada tanggal 25 Februari 2018 pukul 17.00 WIB melalui IGD dengan keluhan batuk, sesak napas, dan nyeri dada. Batuk berdahak sejak 7 bulan yang lalu yang dirasa semakin memberat sejak 2 bulan sebelum masuk RSDM. Sebelum dirawat di RSDM pasien sempat dirawat di RS Panti Waluyo, di RS Panti Waluyo pasien mendapatkan pengobatan rawat jalan dan akhirnya mendapat rujukan ke RSDM.

Pemeriksaan fisik keadaan umum pasien: kesadaran composmentis, pasien tampak lemah, TD 101/70 mmHg, N 95 $\mathrm{x} /$ menit, RR 28 x/menit, S $36,5^{\circ} \mathrm{C}, \mathrm{SpO}$
98\%, kepala dan wajah: tidak ada sianosis, mukosa bibir lembab, leher tidak ada pembesaran kelenjar tiroid, terpasang WSD di sebelah kiri, dada: I: pengembangan dada kanan sama dengan kiri, P: fremitus raba kiri < kanan, P: sonor/dullness ICS II, III, ICS V, VI, A: vesikuler/vesikuler yang menurun ICS II, III, ICS V, VI, Ekstremitas: terpasang infus $\mathrm{NaCl}$ 0,9\% 20 tpm di sebelah kaki sinistra.

Hasil pemeriksaan laboratorium tanggal 5 maret 2018 antara lain hemoglobin $12.5 \mathrm{~g} / \mathrm{dl}$ (normal: 13.5-17.5), hematokrit 42\% (normal: 33-45), leukosit 6.6 ribu/ul (normal: 4.5-11.0), trombosit $374 \mathrm{ribu} / \mathrm{ul}$ (normal: 150-450), eritrosit 5.01 juta/ul (normal: 1.50-5.90), PT 13.2 detik (normal: 10,0-15.0), APTT 6 detik (normal: 20.0-40.0), natrium darah 139 mmol/L (normal: 136-145), kalium darah $3.7 \mathrm{mmol} / \mathrm{L}$ (normal: 3.3-5.1), chlorida darah $101 \mathrm{mmol} / \mathrm{L}$ (normal: 98-106).

Hasil pemeriksaan laboratorium mikrobiologi klinik antara lain bahan cairan pleura kiri pengecatan gram hasilnya tidak ditemukan bakteri, leukosit $2+$, epithel negative, dan pengecataan BTA hasil negative. Bahan cairan pleura kanan pengecatan gram hasilnya tidak ditemukan bakteri, leukosit 1+, epithel 1+ dan pengecatan BTA hasil negatif. Bahan bilasan bronkus pengecatan gram hasilnya tidak ditemukan bakteri, leukosit 1+, epithel negative, dan pengecatan BTA hasil negatif.

Hasil pemeriksaan radiologi 1 Maret 2018 diperoleh kesimpulan: Massa mediastinum superior hingga medius yang meluas ke dinding dada anterior $\&$ encase pada aorta dan A pulmonalis bilateral suspek Thymoma.Limfadenopati paratrakeal, peribronkial, dan paraaorta. Efusi pleura bilateral, sudah terpasang 
WSD kiri dengan tip terproyeksi di SIC 6 posterior kiri dan pneumonic reaction metastase. VCSS (Vena Cava Superior Syndrom).

Program Terapi yang didapat antara lain oksigen nasal kanul 3 liter/menit, diet Tinggi kalori Tinggi Protein (TKTP), paracetamol $650 \mathrm{mg} / 6 \mathrm{jam}, \mathrm{N}$-asetilsistein $200 \mathrm{mg} / 8 \mathrm{jam}$, curcuma $1 \mathrm{tab} / 8 \mathrm{jam}, \mathrm{NaCl}$ 0,9\% 20 tpm, SNMC dalam $\mathrm{NaCl} 100 \mathrm{cc}$ : $2 \mathrm{amp} / 24 \mathrm{jam}$ atau $1 \mathrm{amp} / 24 \mathrm{jam}$.

b. Pasien 2

Pengkajian dilakukan pada tanggal 12 Maret 2018 pukul 15.00 WIB di ruang HCU Anggrek 1 RS Dr. Moewardi Surakarta. Data didapat dari hasil observasi, wawancara langsung, pemeriksaan fisik, dan dari status pasien. Dari hasil pengkajian diperoleh data nama pasien adalah Tn. J, jenis kelamin lakilaki, alamat rumah Surakarta, usia 50 tahun, pendidikan SMP, pekerjaan wiraswasta, status perkawinan menikah, No RM 01072xxx, Dx. medis efusi pleura. Identitas Penanggung Jawab Nama Ny. N, jenis kelamin perempuan, alamat rumah Surakarta, pekerjaan swasta, hubungan dengan pasien adalah anak.

Keluhan utama yang dirasakan pasien yaitu sesak napas dan batuk berdahak. Riwayat penyakit sekarang yaitu pasien masuk rumah sakit pada tanggal 11 Maret 2018 pukul 18.00 WIB melalui IGD dengan keluhan sesak napas, dan batuk disertai dahak putih kental. Sesak napas sejak satu minggu sebelum masuk rumah sakit, sesak napas dipengaruhi aktivitas. Pasien sudah sempat dirawat di RS lain dan dikatakan paru-paru basah hinga akhirnya mendapat rujukan ke RSDM. Riwayat penyakit dahulu yaitu pasien mengatakan memiliki riwayat pengobatan OAT (pengobatan TBC) tuntas pada tahun 2012. Riwayat penyakit keluarga yaitu di dalam keluarga pasien tidak ada yang menderita penyakit paru ataupun penyakit menular lainya.

Hasil pengkajian primer yaitu airway: bebas sumbatan jalan napas, suara napas vesikuler ICS II, III, ICS V, VI. Breathing: pasien mengeluh sesak napas, RR 25 x/menit, bunyi napas vesikuler ICS II, III, ICS V, VI, irama napas teratur, tidak ada tanda distres pernapasan. Circulation: akral hangat, tidak pucat, tidak ada sianosis, CRT < 2 detik, nadi 87 $\mathrm{x} /$ menit, irama nadi teratur kuat, TD 130/89 mmHg, kulit lembab, turgor kulit normal. Disability: tingkat kesadaran composmentis, GCS $\mathrm{E}_{4} \mathrm{~V}_{5} \mathrm{M}_{6}$, pupil isokor, reflek cahaya $+/+$, besar pupil 3/3. Eksposure: tidak ada trauma, tidak ada jejas pada tubuh, tidak ada deformitas, tidak ada hematoma, dan tidak terdapat edema.

Hasil pengkajian sekunder yaitu Sign and Symptoms: pasien mengalami sesak napas, dan batuk disertai dahak putih kental. Allergies: pasien tidak ada alergi obat, debu, makanan. Medication: pasien tidak sedang menjalani pengobatan lain. Past illnes: Riwayat pengobatan OAT tuntas pada tahun 2012. Last oral intake: saat ini pasien mengkonsumsi obat dari RS. Event: Pasien masuk rumah sakit pada tanggal 11 Maret 2018 pukul 18.00 WIB melalui IGD dengan keluhan sesak napas, dan batuk disertai dahak putih kental. Sesak napas sejak satu minggu sebelum masuk rumah sakit, sesak napas dipengaruhi aktivitas. Pasien sudah sempat dirawat di RS lain dan dikatakan paru-paru basah hinga akhirnya mendapat rujukan ke RSDM.

Pemeriksaan fisik didapatkan hasil keadaan umum pasien saat dilakukan pengkajian: kesadaran composmentis, pasien tampak lemah, TD 130/89 $\mathrm{mmHg}$, 
N 87 x/menit, RR 25 x/menit, S $36,2{ }^{\circ} \mathrm{C}$, $\mathrm{SpO}_{2} 97 \%$, kepala dan wajah tidak ada sianosis, mukosa bibir lembab, leher tidak ada pembesaran kelenjar tiroid, dada I: pengembangan dada kanan sama dengan kiri, P: fremitus raba kanan sama dengan kiri, P: sonor/sonor, A : vesikuler/vesikuler, ekstremitas terpasang infus $\mathrm{NaCl}$ 0,9\% 20 tpm di sebelah tangan kanan.

Hasil pemeriksaan laboratorium tanggal 11 maret 2018 antara lain Hb14,5g/dl (normal: 13,5 - 17,5), natrium darah $132 \mathrm{mmol} / \mathrm{L}$ (normal: 136-145), kalium darah $3.3 \mathrm{mmol} / \mathrm{L}$ (normal: 3.3 5.1), chlorida darah $97 \mathrm{mmol} / \mathrm{L}$ (normal: 98-106), pH 7.575 (normal: 7.350-7.450), $\mathrm{BE} 4.5 \mathrm{mmol} / \mathrm{L}$ (normal: $-2-+3$ ), $\mathrm{pCO}_{2}$ $28.5 \mathrm{mmHg}$ (normal: 27.0-41.0), $\mathrm{pO}_{2} 70.9$ $\mathrm{mmHg}$ (normal: 83.0-108.0), hematokrit $42 \%$ (normal: 37-50), $\mathrm{HCO}_{3} 26.6 \mathrm{mmol} / \mathrm{L}$ (normal: 21.0-28.0), total $\mathrm{CO}_{2} 27.5$ mmol/L (normal: 19.0-24.0), $\mathrm{O}_{2}$ saturasi 95.3\% (normal: 94.0-98.0).

Hasil pemeriksaan laboratorium mikrobiologi klinik yaitu bahan sputum: pengecatan gram hasilnya Ditemukan kuman gram + coccus dan gram negatif batang, leukosit 2+, ephitel 1+ dan pengecataan BTA dari sputum hasilnya negatif.

Hasil pemeriksaan radiologi 13 Maret 2018 diperoleh kesimpulan klinis: pneumonia bakterial, BE terinfeksi, bekas TB dd relaps. Tampak gambaran signet ring sign multipe, sebagian bergerombol di kedua lapang paru tipe silinder varicose dan cystic disertai dround glass opociti disekitarnya. Tampak lesidensitas cairan pleura kiri minimal.

Program terapi yang didapat antara lain oksigen nasal kanul 3 liter/menit, diet TKTP, terapi obat : amoxicillin 1,2 gr/8jam, asetilsistein $200 \mathrm{gr} / 8 \mathrm{jam}$, curcuma $3 \times 1$, neurodex $3 \times 1$, ciproflaxin $400 \mathrm{mg} / 12 \mathrm{jam}$.

\section{Diagnosa Keperawatan}

Berdasarkan pengkajian yang dilakukan pada Tn. D dan Tn. J dapat ditegakkan diagnosa keperawatan pada Tn. D dan Tn. J dengan penyakit efusi pleura, yaitu: Pola napas tidak efektif berhubungan dengan penurunan ekspansi paru sekunder terhadap penumpukan cairan dalam rongga pleura.

3. Intervensi Keperawatan

Pola napas tidak efektif berhubungan dengan penurunan ekspansi paru sekunder terhadap penumpukan cairan dalam rongga pleura.

Tujuan yang ingin dicapai setelah dilakukan tindakan keperawatan dalam waktu $3 \times 8$ jam diharapkan pola napas kembali efektif. Kriteria hasil yang ingin dicapai antara lain irama, frekuensi dan kedalaman pernapasan dalam batas normal, pada pemeriksaan thorax tidak ditemukan akumulasi cairan dan bunyi napas terdengar jelas. Intervensi keperawatan yang dilakukan kaji frekuensi kedalaman pernapasan dan ekspansi dada serta catat upaya pernapasan termasuk penggunaan otot bantu pernapasan, kaji secara rutin kulit, kuku dan warna dan perubahan yang terjadi pada membran mukosa bibir, observasi tanda-tanda vital dan status jantung, lakukan auskultasi suara napas dan catat adanya bunyi napas, atur posisi semifowler, ajarkan pasien pernapasan diafragma, kolaborasi dalam pemberian obat dan $\mathrm{O}_{2}$.

4. Implementasi Keperawatan

a. Tn. D

Pada hari Senin, 5 Maret 2018 telah dilakukan tindakan keperawatan pada Tn.D antara lain mengkaji frekuensi kedalaman pernapasan dan ekspansi dada. Mencatat upaya pernapasan termasuk 
penggunaan otot bantu pernapasan $(15.00$ WIB), mengkaji kulit, kuku dan warna dan perubahan yang terjadi pada membran mukosa bibir (15.00 WIB), mengobservasi tanda-tanda vital dan status jantung (15.00 WIB), melakukan auskultasi suara napas dan catat adanya bunyi napas (15.00 WIB), mengatur posisi semifowler (16.00 WIB), berkolaborasi dalam pemberian obat dan $\mathrm{O}_{2}$ (17.00 WIB), mengajarkan pasien pernapasan diafragma (18.00 WIB), mengobservasi tanda-tanda vital dan status jantung (20.00 WIB). Kemudian hari Selasa, 6 Maret 2018 telah dilakukan tindakan keperawatan antara lain mengkaji frekuensi kedalaman pernapasan dan ekspansi dada. Mencatat upaya pernapasan termasuk penggunaan otot bantu pernapasan (15.00 WIB), mengkaji kulit, kuku dan warna dan perubahan yang terjadi pada membran mukosa bibir (15.00 WIB), mengobservasi tanda-tanda vital dan status jantung (15.00 WIB), mengatur posisi semifowler (17.00 WIB), berkolaborasi dalam pemberian obat dan $\mathrm{O}_{2}$ (19.00 WIB), mengobservasi tanda-tanda vital dan status jantung (20.00 WIB). Kemudian hari Rabu, 7 Maret 2018 telah dilakukan tindakan keperawatan antara lain mengkaji frekuensi kedalaman pernapasan dan ekspansi dada. Mencatat upaya pernapasan termasuk penggunaan otot bantu pernapasan (14.30 WIB), mengkaji kulit, kuku dan warna dan perubahan yang terjadi pada membran mukosa bibir (14.30 WIB), mengobservasi tanda-tanda vital dan status jantung (14.30 WIB), mengatur posisi semifowler (15.30 WIB), berkolaborasi dalam pemberian obat dan $\mathrm{O}_{2}$ (17.00 WIB), mengobservasi tanda-tanda vital dan status jantung (18.00 WIB). b. Tn. J

Pada hari Senin, 12 Maret 2018 telah dilakukan tindakan keperawatan pada Tn. $\mathrm{J}$ antara lain mengkaji frekuensi kedalaman pernapasan dan ekspansi dada. Mencatat upaya pernapasan termasuk penggunaan otot bantu pernapasan (14.00 WIB), mengkaji kulit, kuku, dan warna dan perubahan yang terjadi pada membran mukosa bibir (14.00 WIB), mengobservasi tanda-tanda vital dan status jantung (14.00 WIB), melakukan auskultasi suara napas dan catat adanya bunyi napas (14.00 WIB), mengatur posisi semifowler (14.30 WIB), berkolaborasi dalam pemberian obat dan $\mathrm{O}_{2}$ (15.00 WIB), mengajarkan pasien pernapasan diafragma (16.00 WIB), mengobservasi tanda-tanda vital dan status jantung (17.00 WIB). Kemudian hari Selasa, 13 Maret 2018 telah dilakukan tindakan keperawatan antara lain mengkaji frekuensi kedalaman pernapasan dan ekspansi dada. mencatat upaya pernapasan termasuk penggunaan otot bantu pernapasan (14.00 WIB), mengkaji kulit, kuku dan warna dan perubahan yang terjadi pada membran mukosa bibir (14.00 WIB), mengobservasi tanda-tanda vital dan status jantung (14.00 WIB), mengatur posisi semifowler (15.00 WIB), berkolaborasi dalam pemberian obat dan $\mathrm{O}_{2}$ (17.00 WIB), mengobservasi tanda-tanda vital dan status jantung (19.00 WIB). Kemudian hari Rabu, 14 Maret 2018 telah dilakukan tindakan keperawatan antara lain mengkaji frekuensi kedalaman pernapasan dan ekspansi dada. Mencatat upaya pernapasan termasuk penggunaan otot bantu pernapasan (15.00 WIB), mengkaji kulit, kuku, dan warna dan perubahan yang terjadi pada membran mukosa bibir (15.00 WIB), mengobservasi tanda-tanda vital dan status jantung (15.00 WIB), 
mengatur posisi semifowler (15.30 WIB), berkolaborasi dalam pemberian obat dan $\mathrm{O}_{2}$ (17.00 WIB), mengobservasi tandatanda vital dan status jantung (18.00 WIB).

\section{Evaluasi Keperawatan}

Evaluasi keperawatan pada Tn. D dilakukan tanggal 7 Maret 2018 pada pukul 20.30 WIB. Diagnosa pola napas tidak efektif berhubungan dengan penurunan ekspansi paru sekunder terhadap penumpukan cairan dalam rongga pleura dengan analisis masalah teratasi sebagian, dibuktikan dengan pasien mengatakan sesak napas berkurang, pasien mengatakan nyaman dengan posisi semifowler, pasien bernapas menggunakan otot bantu pernapasan, tidak ada sianosis, TD: $115 / 80 \mathrm{mmHg}, \mathrm{N}$ : $85 \mathrm{x} /$ menit, RR: $23 \mathrm{x} /$ menit, $\mathrm{S}: 36,6{ }^{\circ} \mathrm{C}$, $\mathrm{SpO}_{2}: 99 \%$.

Evaluasi keperawatan pada Tn. J dilakukan tanggal 14 Maret 2018 pada pukul 20.00 WIB. Diagnosa pola napas tidak efektif berhubungan dengan penurunan ekspansi paru sekunder terhadap penumpukan cairan dalam rongga pleura dengan analisis masalah teratasi sebagian, dibuktikan dengan pasien mengatakan sesak napas berkurang, pasien mengatakan nyaman dengan posisi semifowler, pasien bernapas menggunakan otot bantu pernapasan, tidak ada sianosis, TD 142/97 $\mathrm{mmHg}, \mathrm{N}$ : $89 \mathrm{x} / \mathrm{menit}$, RR: $22 \mathrm{x} / \mathrm{menit}, \mathrm{S}: 36,6{ }^{0} \mathrm{C}$, $\mathrm{SpO}_{2}: 100 \%$.

\section{PEMBAHASAN}

Pada pembahasan ini, peneliti menjelaskan dua pasien efusi pleura dengan gangguan pola napas tidak efektif saat sebelum diberi tindakan dan sesudah diberi tindakan. Kemudian peneliti membandingkan hasil evaluasi dari masing-masing pasien setelah dilakukan tindakan keperawatan yang didukung oleh teori dan jurnal.

Pengkajian pada Tn. D didapatkan data pasien mengatakan sesak napas, batuk berdahak, dan nyeri dada. Pasien mengatakan sesak napas dirasakan semakin memberat ketika pasien tidur dengan posisi terlentang. Pasien tampak lemah, bernapas menggunakan otot bantu pernapasan. Tanda- tanda vital: TD: 101/70 mmHg, N: 95 x/menit, RR: 28 $\mathrm{x} / \mathrm{menit}, \mathrm{S}: 36,5{ }^{0} \mathrm{C}, \mathrm{SpO}_{2}: 98 \%$. Dari data tersebut maka dapat ditegakkan diagnosa keperawatan pola napas tidak efektif berhubungan dengan penurunan ekspansi paru sekunder terhadap penumpukan cairan dalam rongga pleura. Setelah disusun intervensi keperawatan dan kemudian dilakukan implementasi keperawatan selama $3 \times 8$ jam diperoleh hasil dari respon pasien. Pasien mengatakan sesak napas berkurang, nyaman dengan posisi semifowler, pasien tampak lemah, bernapas menggunakan otot bantu pernapasan, tanda- tanda vital: TD: 115/80 mmHg, N: 85 x/menit, RR: 24 $\mathrm{x} / \mathrm{menit}, \mathrm{S}: 36,5{ }^{\circ} \mathrm{C}, \mathrm{SpO}_{2}: 99 \%$. Dari hasil tersebut maka masalah keperawatan teratasi sebagian dan intervensi dilanjutkan.

Pengkajian pada Tn. J didapatkan data pasien mengatakan sesak napas, batuk berdahak putih kental. Pasien mengatakan sesak napas dirasakan semakin memberat ketika pasien tidur dengan posisi terlentang. Pasien tampak lemah, bernapas menggunakan otot bantu pernapasan. Tanda- tanda vital: TD: $130 / 89 \mathrm{mmHg}, \mathrm{N}$ : $87 \mathrm{x} /$ menit, RR: $25 \mathrm{x} / \mathrm{menit}, \mathrm{S}: 36,2^{\circ} \mathrm{C}$, $\mathrm{SpO}_{2}: 97 \%$. Dari data tersebut maka dapat ditegakkan diagnosa keperawatan pola napas tidak efektif berhubungan dengan penurunan ekspansi paru sekunder 
terhadap penumpukan cairan dalam rongga pleura. Setelah disusun intervensi keperawatan dan kemudian dilakukan implementasi keperawatan selama $3 \times 8$ jam diperoleh hasil dari respon pasien. Pasien mengatakan sesak napas berkurang, nyaman dengan posisi semifowler, pasien tampak lemah, bernapas menggunakan otot bantu pernapasan, tanda- tanda vital: TD: 142/97 mmHg, N: 89 x/menit, RR: 22 x/menit, S: $36,6^{\circ} \mathrm{C}, \mathrm{SpO}_{2}: 100 \%$. Dari hasil tersebut maka masalah keperawatan teratasi sebagian dan intervensi dilanjutkan.

Saat dilakukan pengkajian ditemukan perbedaan tidakan Tn. D terpasang WSD sedangkan pada Tn. J tidak terpasang WSD. Perbedaan tersebut terjadi karena produksi cairan pleura yang berbeda. Pada Tn. D produksi cairannya banyak sedangkan pada Tn. J sedikit yg dibuktikan dengan hasil radiologi yang menyatakan bahwa tampak lesidensitas cairan pleura kiri minimal. Menurut Ari 2008 dalam Adipratiwi (2015) WSD adalah suatu sistem drainage yang menggunakan water sealed untuk mengalirkan udara atau cairan dari cavum pleura (rongga pleura) tujuannya adalah untuk mengalirkan udara atau cairan dari rongga pleura untuk mempertahankan tekanan negatif rongga tersebut, dalam keadaan normal rongga pleura memiliki tekanan negatif dan hanya terisi sedikit cairan pleura.

Pada Tn. D efusi pleura disebabkan oleh adanya tumor mediastinum. Menurut Nurarif dan Kusuma (2015) tumor merupakan suatu keganasan yang diawali dengan nekrotik jaringan. Nekrotik jaringan dapat menyebabkan reabsorbsi cairan terganggu kemudian terjadi penumpukan cairan pada rongga pleura. Sedangkan pada Tn. J efusi pleura disebabkan oleh adanya peradangan pada pleura yg diakibatkan bekas TB yang relaps. Menurut Nurarif dan Kusuma (2015) peradangan pleura dapat menyebabkan permeabel membran kapiler meningkat sehingga cairan protein dari getah bening masuk ke rongga pleura. Perbedaan etiologi penyakit inilah yang akan menyebabkan kondisi pasien juga berbeda.

Kedua pasien mengatakan sesak napas berkurang. Berdasarkan jurnal Yuningsih (2017) pasien yang melakukan napas dalam ataupun pernapasan diafragma tersebut dapat meningkatkan saturasi oksigen. Hal ini dibuktikan dalam penelitiannya yang diperoleh hasil ratarata saturasi sebelum dilakukan nafas dalam pada pagi hari : 96,86 \% dan setelah dilakukan nafas dalam pada siang hari : 97,67\%. Dari hasil tersebut terdapat peningkatan saturasi. Dengan peningkatan saturasi oksigen inilah menunjukkan sesak napas pasien berkurang.

Kedua pasien mengatakan nyaman dengan posisi semi fowler. Berdasarkan jurnal Annisa, Utomo, \& Utami (2015), pada posisi telentang individu mengalami dua proses fisiologi yang dapat menekan pernafasan yaitu peningkatan volume darah dalam rongga toraks dan kompresi dada. Akibatnya, proses pertukaran udara pada seseorang yang berbaring telentang tidak berlangsung secara maksimal. Sedangkan pada posisi semi fowler ini menunjukkan peningkatan posisi badan condong kedepan yang dapat meningkatkan fungsi ventilasi paru. Posisi badan yang condong kedepan atau keatas inilah yang mengakibatkan organ abdominal tidak menekan diafrgama sesuai dengan tingkat kenaikan posisi fowler. Sehingga dengan posisi 
semifowler inilah pasien akan merasakan nyaman saat bernapas.

Terdapat perbedaaan peningkatan saturasi oksigen pada kedua pasien. Pada Tn. D saturasi awalnya $98 \%$ setelah diberi oksigen 3 liter/menit naik menjadi 99\%, sehingga didapatkan kenaikan sebesar $1 \%$. Sedangkan pada Tn. J saturasi awalnya 97\% setelah diberi oksigen 3 liter/menit naik menjadi $100 \%$, sehingga didapatkan kenaikan sebesar $3 \%$. Perbedaan kenaikan ini disebabkan karena kadar Hemoglobin ( $\mathrm{Hb})$ dalam darah yang berbeda, pada Tn. D kadar Hbnya rendah yaitu 12,5 g/dl sedangkan pada Tn. J kadar Hbnya normal yaitu 14,5 g/dl. Kadar $\mathrm{Hb}$ yang rendah inilah dapat mengurangi pasokan oksigen yang sampai ke jaringan.

Terdapat perbedaan penurunan RR pada kedua pasien. Sebelum dilakukan asuhan keperawatan RR Tn. D 28 x/menit, kemudian setelah dilakukan asukan keperawatan menjadi $24 \mathrm{x} /$ menit. Sedangkan untuk Tn. J RR awal 25 $\mathrm{x} /$ menit menjadi $22 \mathrm{x} /$ menit.Kedua pasien tersebut sama-sama nengalami penurunan RR, tetapi RR Tn. D tetap tinggi dikarenakan terdapat diagnosa tumor mediastinum. Menurut jurnal Pratama, Syahruddin, \& Hudoyo (2014) Tumor mediastinum adalah tumor yang terdapat di dalam rongga mediastinum yaitu rongga yang berada diantara paru kanan dan kiri. Gejala klinis dapat dibagi dalam dua kelompok yaitu gejala respirasi dan nonrespirasi. Gejala respirasi pada pasien tumor mediastinum ditemukan pada 87 orang dan yang terbanyak adalah batuk 68 $(78,1 \%)$ orang, sesak napas $60(68,9 \%)$, nyeri dada $39(44,8 \%)$ dan paling sedikit napas berbunyi $2(2,3 \%)$. Sehingga tumor mediastinum mempengaruhi respirasi.

\section{KESIMPULAN DAN SARAN}

1. Kesimpulan

Setelah dilakukan tindakan keperawatan pada Tn. D dan Tn. J dengan efusi pleura di ruang HCU Melati RSUD Dr. Moewardi Surakarta peneliti membuat beberapa kesimpulan:

a. Sebelum dilakukaan asuhan keperawatan pada masalah pola napas tidak efektif pada Tn. D mengatakan sesak napas, batuk berdahak, dan nyeri dada. Tanda- tanda vital: TD: 101/70 mmHg, N: 95 x/menit, RR: 28 $\mathrm{x} /$ menit, $\mathrm{S}: 36,5{ }^{0} \mathrm{C}, \quad \mathrm{SpO}_{2}: 98 \%$. Sehingga dapat ditegakkan diagnosa keperawatan pola napas tidak efektif. Setelah dilakukan asuhan keperawatan selama $3 \times 8$ jam diperoleh hasil evaluasi yaitu masalah teratasi sebagian.

b. Sebelum dilakukaan asuhan keperawatan pada masalah pola napas tidak efektif pada Tn. J mengatakan sesak napas, batuk berdahak putih kental. Tanda- tanda vital: TD: $130 / 89$ mmHg, $\mathrm{N}: 87 \mathrm{x} / \mathrm{menit}, \mathrm{RR}: 25$ $\mathrm{x} /$ menit, $\mathrm{S}: 36,2{ }^{0} \mathrm{C}, \quad \mathrm{SpO}_{2}: 97 \%$. Sehingga dapat ditegakkan diagnosa keperawatan pola napas tidak efektif. Setelah dilakukan asuhan keperawatan selama $3 \times 8$ jam diperoleh hasil evaluasi yaitu masalah teratasi sebagian.

c. Setelah dilakukan asuhan keperawatan pada pola napas tidak efektif semua masalah sama-sama teratasi sebagian.

d. Ada perbedaan antara Tn. D dan Tn. J setelah dilakukan asuhan keperawatan pola napas tidak efektif. 
Berdasarkan hasil kesimpulan diatas, maka saran yang dapat peneliti simpulkan adalah:

a. Pada saat melakukan pengkajian, data yang didapat harus lebih lengkap dan akurat sesuai dengan kondisi pasien saat itu, kaji setiap tanda dan gejala yang dirasakan atau yang dialami oleh pasien.

b. Dalam merumusakan diagnosa, sebaiknya disesuaikan dengan kondisi pasien dan data fokusnya.

c. Dalam membuat intervensi dan melakukan implementasi keperawatan perlu dilandasi dengan teori yang ada dan mengacu pada kondisi yang nyata yang dialami oleh pasien pada saat itu juga. Perawat perlu adanya komunikasi antar tim kesehatan dan juga pendelegasian serta penting untuk menerapkan prinsip doble checker yang dilakukan antara tim kesehatan sebelum melakukan pemberian terapi obat kepada pasien.

d. Pada saat evaluasi, perlu dilakukan pengkajian ulang secara subjektif dan objektif serta didukung pemeriksaan fisik agar mengetahui tingkat keberhasilan dari tindakan keperawatan apakah masalah tersebut teratasi atau tidak. Jika masalah teratasi, intervensi apa yang harus dipertahankan dan dihentikan dan jika masalah tidak teratasi atau belum teratasi maka intervensi apa yang harus dilakukan lagi.

\section{DAFTAR RUJUKAN}

Black, J.M \& Hawks, J.H (2009). Medical Surgical Nursing: Clinical Managemen.

Puspita, Soleha, \& Berta, 2015. Penyebab Efusi Pleura di Kota Metro pada tahun 2015. Journal
ArgoMedicine. Universitas Lampung.

Hidayat, A.A..(2014). Metode penelitian keperawatan dan teknis analisis data. Jakarta : Salemba Medika.

Nursalam. (2014). Metodologi Penelitian Ilmu Keperawatan : Pendekatan Praktis, Edisi 3. Jakarta : Salemba Medika

Surjanto E, Sutanto YS, Aphridasari J, dan Leonardo. 2014. Penyebab efusi pleura pada pasien rawat inap di rumah sakit. Jurnal Respirologi Indonesia. 34: 102-108

Suwitra, K. (2009). Buku Ajar Ilmu Penyakit Dalam. Jakarta : Interna Publishing.

Morton P.G, Fontaine D, Hudak C.M, Gallo B.M. (2013). Keperawatan Kritis: Pendekatan Asuhan Holistik Vol.1. Edisi 8. Alih bahasa: Subekti N.B, Yudha E.K, Yulianti D, Nurwahyu, Kapo

Nurarif .A.H. dan Kusuma. H. (2015). APLIKASI Asuhan Keperawatan Berdasarkan Diagnosa Medis \& NANDA NIC-NOC. Jogjakarta: MediAction 